\title{
Combined Effects of Vernalization and Gibberellic Acid on Quality Seed Production of Summer Onion (Allium cepa L.)
}

\author{
Lamia Khatun ${ }^{1}$, Md. Rezaul Karim ${ }^{1}$, Fakhar Uddin Talukder ${ }^{2} \&$ Md. Sohanur Rahman ${ }^{2}$ \\ ${ }^{1}$ Department of Horticulture, Bangladesh Agricultural University, Mymensingh-2202, Bangladesh \\ ${ }^{2}$ Pest Management Division, Bangladesh Jute Research Institute, Manik Mia Avenue, Dhaka-1207, Bangladesh \\ Correspondence: Lamia Khatun, Department of Horticulture, Bangladesh Agricultural University, Mymensingh- \\ 2202, Bangladesh. E-mail: lamiarimi28@gmail.com
}

Received: June 5, 2020 Accepted: September 4, 2020 Published: October 26, 2020

\begin{abstract}
The purpose of the present study was to evaluate the effect of vernalization and GA3 on seed yield and reproductive quality of summer onion. There were three vernalization treatments viz., no vernalization (control), vernalization at $5^{\circ} \mathrm{C}$ for 14 days and vernalization at $10^{\circ} \mathrm{C}$ for 14 days and four GA3 treatment viz., 0, 50, 100 and 150 ppm. The two-factor experiment was conducted in the Randomized Complete Block Design (RCBD) with three replications. Combination between vernalization and GA3 was significant on the parameters such as plant height, number of leaves plant ${ }^{-1}$, the highest number of flowering stalk, number of umbels plant ${ }^{-1}$, number of bud umbel ${ }^{-1}$, percent flowering at 45 and $60 \mathrm{DAP}$, number of seeds $\mathrm{umbel}^{-1}$, weight of seeds umbel ${ }^{-1}$, weight of seeds plant ${ }^{-1}$, weight of seeds plot $^{-1}, 1000$ seed weight, seed yield, number of fruits umbel $^{-1}$, percent of fruit set umbel ${ }^{-1}$ and percent germination. Combined effect of vernalization \& GA3 was considered the highest seed yield $\left(280.42 \mathrm{kgha}^{-1}\right) \mathrm{was}^{-1}$ obtained from vernalization at $5^{\circ} \mathrm{C}$ for 14 days with 100 ppm GA3. The lowest values of all the parameters were recorded in the control treatment. No limitation is found in the present experiment. Combined use of proper vernalization of mother bulb and suitable concentration of gibberellic acid can be one possible way to expand onion production during the summer.
\end{abstract}

Keywords: vernalization, Gibberellic Acid, seed production, onion

\section{Introduction}

Vernalization is a proper process required for some definite plant species, e.g. onion (Allium cepa L.), to enter into the reproductive stage, through an introduction to low but non-freezing temperatures (Streck, 2003). Onion is a herbaceous biennial crop, and the temperature is an environmental factor that is a major controller of its development (Brewster, 1983, 1987; Rabinowitch, 1985). At the time of Onion development, there have a temperature function (Brewster, 1987). The expression of vegetative plants (after a juvenile stage which corresponds to a minimum 7-10 initiated leaves) or bulbs to low temperatures introduces flowering, which terminates the growth of the main axis (Rabinowitch, 1985). The outpouring to low temperatures either in natural winter or in artificial cold treatment which brings about the induction of flowering in plant species (e.g. onion) is called vernalization (Pinthus, 1985; Flood \& Halloran, 1986). Vernalization of onion is an important research interest because of the need to induce flowering for seed production for breeding purposes in the shortest period (Brewster, 1987). Lack of cold temperatures to induce flowering is the main constrain to onion seed production in tropical countries (Kimani et al., 1994). The reaction of plants to vernalization is occurred by the combination of 2 factors, the duration of the vernalization period and the temperature during the vernalization period (Hodges $\&$ Ritchie, 1991; Ritchie, 1991). Brewster (1987) processed data every day vernalization rate to temperature with a stepwise linear function. A step-wise function is not the most suitable response work as a temperature response function because biological systems seem to respond to temperature, continuously and smoothly rather than in a combination of linear functions that introduce sudden changes in the response (Shaykewich, 1995; Streck, 2002a). In the case of onion, a short duration cold treatment of $10^{\circ} \mathrm{C}$ for 10 days enhances the seed yield (Yalamalle 2016). The inoculation of mycorrhizae and the application of humic substances can enhance bulb growth and quality (Sekara et al. 2017). The proper vernalization temperature of mother onion bulbs enhance early flowering and produces a higher yield of onion seed (Khokhar 2014). Vernalization of the bulb is required for flower initiation in onion (Brewster, 1994). The suitable vernalization temperature of the mother bulb incites early flowering and produces a better yield of seed (Jones and Mann, 1963). Gibberellins are one of the major regulators of plant 
growth and development which suppress the growth and promoting cell elongation and division (Olszewski et al., 2002; Ubeda Tomas et al., 2009). It is well known that GA3 enhances plant growth and its accompanying metabolite production (Jones et al., 2009). The applications of gibberellic acid (GA3) on plants promote plant height and, secondarily, increase dry weight (Sharma et al. 1999). The effect of GA3 on onion seed production is characterized by an increase in the number of inflorescences per plant, and synchronization of pistillate \& staminate patterns (Corgan and Montano 1975). Medium or large bulbs sprayed with Gibberellic acid at 50ppm provide significantly higher seed yield per hectare, germination, and vigor (Shaikh et al. 2002). Spraying of GA3 on plants increased seed yield and quality parameters compared with controls (Rizk et al. 1996). One of the most important problems is the unavailability of good quality seeds due to a lack of cold temperatures for summer onion seed production. The proper vernalization temperature of the mother bulb stimulates early flowering and produces a heavier yield of seed (Jones and Mann, 1963). Plant growth regulators (e.g. gibberellic acid) are new generation agrochemicals and are expected to play an important role in overcoming the hurdles in the manifestation of biological yield. To meet up the demand for onion in Bangladesh, one possible solution is to expand onion production during the summer season. The present research work has been undertaken to find out the appropriate vernalized temperature with a proper dose of GA3 for obtaining a maximum yield of summer onion seed.

\section{Materials and Methods}

\subsection{Experimental Site, Soil, Climate}

The present research work was conducted at the Horticultural Farm, Bangladesh Agricultural University, Mymensingh during the period from November 2017 to April 2018. The experimental area is located at $24^{\circ} 46^{\prime} \mathrm{N}$ latitude and $90^{\circ} 24^{\prime} \mathrm{E}$ longitude. The experimental area belongs to Old Brahmaputra Flood Plain under the AEZ number-9. The field was above inundation level and texturally silty loam with a $\mathrm{pH}$ value 6.8 . The climate of the experimental area was sub-tropical, characterized by heavy or scanty rainfall.

\subsection{Experimental Material}

The bulbs (Different size graded) of summer onion variety BARI Piaz-3 were used in this study. These seed bulbs were collected from Bangladesh Agricultural Research Institute, Gazipur. The distance maintained between the rows was $25 \mathrm{~cm}$ and between the plants was $20 \mathrm{~cm}$ and each unit plot accommodated 20 plants.

\subsection{Experimental Treatments}

The experiment had two factors. The levels of each factor were

\section{Factor A: Vernalization}

$\mathrm{V}_{0}=$ No vernalization, $\mathrm{V}_{1}=$ Vernalization at $5^{\circ} \mathrm{C}$ for 14 days, $\mathrm{V}_{2}=$ Vernalization at $10^{\circ} \mathrm{C}$ for 14 days

Factor B: Concentrations of $\mathrm{GA}_{3}$

$\mathrm{G}_{0}=0 \mathrm{ppm}, \mathrm{G}_{1}=50 \mathrm{ppm}, \mathrm{G}_{2}=100 \mathrm{ppm}, \mathrm{G}_{3}=150 \mathrm{ppm}$

\subsection{Design and Layout of the Experiment}

The two-factor experiment consisting of twelve treatment combinations was laid out in the Randomized Complete Block Design (RCBD) with three replications. Thus in total 36 unit plots were obtained. The total area of this experiment was divided into three blocks and each blocks contained twelve plots. The treatment combinations were randomly placed to unit plots in each blocks. The size of each unit plot was $1 \mathrm{~m} \times 1 \mathrm{~m}$. The distance between the blocks was $75 \mathrm{~cm}$ and between the plots was $50 \mathrm{~cm}$.

\subsection{Vernalization of Mother Bulbs}

Selected bulbs of the same size were put in white cotton cloth bags. Bulbs were then vernalized for 14 days in two different refrigerators calibrated at $5{ }^{\circ} \mathrm{C}$ and $10{ }^{\circ} \mathrm{C}$.

\subsection{Planting of Bulbs in the Experimental Plot}

Bulbs were taken out from the refrigerators four hours prior to planting and then kept under ceiling fan for surface drying. The distance maintained between the row was $25 \mathrm{~cm}$ and between the plant was $20 \mathrm{~cm}$.

\subsection{Preparation of $\mathrm{GA}_{3}$ Solution and Its Application}

Laboratory grade reagents were used to prepare 50,100 and $150 \mathrm{ppm}$ of $\mathrm{GA}_{3}$ solution. The stock solution of 1000 ppm of $\mathrm{GA}_{3}$ was prepared by protein $1.0 \mathrm{gm}$. of $\mathrm{GA}_{3}$ into a conical flask. Then a little amount of ethyl alcohol $\left(\mathrm{C}_{2} \mathrm{H}_{5} \mathrm{OH}\right)$ was added into the conical flask. Then the flask was stirred for some time and exact volume in the volumetric flask was made up by adding distilled water with frequent stirring to have the desired $1 \mathrm{~L}$ stock solution. The stock solution was then preserved in glass jars at low temperature in a refrigerator for preparing solutions of 
desired concentrations. To prepare three concentrations of $\mathrm{GA}_{3}$ solution of 50,100 and $150 \mathrm{ppm}$; at first 50,100 and $150 \mathrm{ml}$ solution had taken from $\mathrm{GA}_{3}$ stock solution $(1000 \mathrm{ppm})$ and then ware diluted to prepare 1 liter volume with the required amount of distilled water. The prepared solutions were sprayed over the plants in two times one at 30 and 50 days after planting (DAP). The solutions were sprayed as foliar spray with the help of hand sprayer.

\subsection{Harvesting}

Matured seed umbels were harvested in several installments when $10-20 \%$ of the capsules were splited and exposed their black seeds. Umbels were harvested with a small portion of flowering stalk in the morning to prevent shattering of seed.

\subsection{Postharvest Operation}

Harvested umbels were dried in open sunlight on brown paper for 4-5 days. Threshing was done manually, seed were cleaned and were dried again until they reached safe moisture content (Brewster, 1994). Seeds were then kept in polythene bag, which were kept in refrigerator at $8 \pm 10^{\circ} \mathrm{C}$.

\subsection{Germination test}

Germination percentage of onion seed was recorded in the Postgraduate Laboratory of the Department of Horticulture, BAU, Mymensingh at ambient room temperature immediately after drying seeds with 3 replications. For each treatment 75 seeds were taken. It was performed following TP (top of paper) method and in sterile petridish (90 mm diameter). In each petridish 25 seeds were placed (for each replication) on three layer of tissue paper saturated with water. Germination data were collected at $7^{\text {th }}$ day of testing.

\subsection{Data Collection}

Data were collected from selected plants in each unit plot. To avoid border effect with the highest precision six plants were selected randomly from each plot out of 30 discarding the outer two rows and outer plants of the middle lines.

\section{Plant height}

The height of plants was measured from ground level to the tip of the longest leaf. Average plant height was determined from selected plants at 20,40 and 60 DAP in centimeter $(\mathrm{cm})$.

\section{Number of leaves plant ${ }^{-1}$}

Number of leaves including green and dry from six selected plants were recorded at 20, 40 and 60 DAP.

\section{Height of flowering stalk}

It was measured from ground level to the tip of the scape before harvest, and the average was recorded in centimeter $(\mathrm{cm})$ from selected plants.

\section{Number of umbels plant $^{-1}$}

Average number of umbels per plant was recorded from randomly selected plants at full bloom stage.

\section{Number of fruits umbel ${ }^{-1}$}

Average number of seeded fruits per umbel was computed from randomly selected six sampled umbels, after harvesting.

\section{Number of bud umbel ${ }^{-1}$}

Average number of buds per umbel was computed from randomly selected six sampled umbels at maximum flowering stage and the average number was recorded.

\section{Percent flowering plants}

The number of plants flowered was conducted at 5 days interval from initiation to completion. Percentage was determined by the following formula:

No. of plants flowered

Percent flowering plants $=$

Total no. of plants in the plot $\times 100$ 


\section{Number of seeds umbel $^{-1}$}

Average number of seeds per umbel was computed from randomly selected six sampled umbels at maximum flowering stage and the average number was recorded.

Weight of seeds umbel ${ }^{-1}$

Average weight of seed per umbel was determined in gram (g) from randomly selected 6 umbels.

Weight of seeds plant ${ }^{-1}$

It was recorded from randomly selected 6 plants and was expressed in gram $(\mathrm{g})$.

Weight of seeds plot $^{-1}$

Total amount of seeds for each plot were bulked and weighted in gram (g).

Percent of fruit set umbel $^{-1}$

The average number of seeded fruits per umbel was recorded from randomly selected 6 sampled umbels after harvesting. Then it was counted per plot. Seeded fruits divided by no. of flowers per umbel were calculated as $\%$ fruit set.

Number of umbels plot ${ }^{-1}$

Average number of umbels per plot was determined from previously selected six plants.

Yield of seeds plant ${ }^{-1}$

The seed were collected, weighed and recorded from randomly selected six plants and the mean weight was expressed in gram $(\mathrm{g})$.

Yield of seeds plot ${ }^{-1}$

Total amount of seeds for each plot was bulked, was weighed and was expressed in gram (g).

Seed yield $\left(\mathrm{kg} \mathrm{ha}^{-1}\right)$

It was determined from conversion of the respective seed yield per plot to ha and was expressed in $\mathrm{kg}$ per ha.

1000 seed weight

For each plot 1000 seeds were counted and weighed by electric balance and was recorded in gram (g).

\section{Germination percentage}

The number of seeds germinated was recorded respectively for each petridish daily. Seeds were considered to have germinated when radical emerged about $2 \mathrm{~mm}$ from the seed. The germination percentage was determined by the following formula.

\section{Germination percentage $=\overline{\text { Not }} \times 100$ \\ No. of seeds set for germination}

\subsection{Statistical Analysis}

The collected data were statistically analyzed by the computer using statistical package programme MSTAT-C. The analysis of variance was performed by $\mathrm{F}$ variance test. The pair of comparisons were performed by Least Significant Difference (LSD) test at 5\% and 1\% level of probability (Gomez and Gomez, 1984).

\section{Results}

\subsection{Combined Effects of Vernalization and GA3 on Plant Height}

The interaction effect of vernalization and GA3 on the plant height of onion was found to be significant at 20 DAP, 40 DAP and 60 DAP. The variation among the treatment combinations was significant. In general, plant height increased gradually with the advancement of time upto 60 DAP (Table 1). The highest plant $(52.75 \mathrm{~cm})$ at 60 DAP was recorded from the treatment combination of V1G2 (vernalization at $5^{\circ} \mathrm{C}$ with 100 ppm GA3) and 60 DAP the lowest height $(40.80 \mathrm{~cm})$ was recorded from the V2G0 treatment combination (Table 1). 
Table 1. Combined effects of vernalization and $\mathrm{GA}_{3}$ concentration on plant height of summer onion at different days after planting

\begin{tabular}{|c|c|c|c|}
\hline \multirow{3}{*}{$\begin{array}{l}\text { Treatment } \\
\text { combination }\end{array}$} & \multicolumn{3}{|c|}{ Plant height $(\mathrm{cm})$ at } \\
\hline & \multicolumn{3}{|c|}{ Days after planting (DAP) } \\
\hline & 20 & 40 & 60 \\
\hline $\mathrm{V}_{0} \mathrm{G}_{0}$ & 11.33 & 32.83 & 41.85 \\
\hline $\mathrm{V}_{0} \mathrm{G}_{1}$ & 11.83 & 34.33 & 44.67 \\
\hline $\mathrm{V}_{0} \mathrm{G}_{2}$ & 14.50 & 44.00 & 50.00 \\
\hline $\mathrm{V}_{0} \mathrm{G}_{3}$ & 14.17 & 39.67 & 46.75 \\
\hline $\mathrm{V}_{1} \mathrm{G}_{0}$ & 20.50 & 37.67 & 42.33 \\
\hline $\mathrm{V}_{1} \mathrm{G}_{1}$ & 20.83 & 41.50 & 46.80 \\
\hline $\mathrm{V}_{1} \mathrm{G}_{2}$ & 23.17 & 45.33 & 52.75 \\
\hline $\mathrm{V}_{1} \mathrm{G}_{3}$ & 21.17 & 43.50 & 49.00 \\
\hline $\mathrm{V}_{2} \mathrm{G}_{0}$ & 16.83 & 34.33 & 40.80 \\
\hline $\mathrm{V}_{2} \mathrm{G}_{1}$ & 16.91 & 37.33 & 45.72 \\
\hline $\mathrm{V}_{2} \mathrm{G}_{2}$ & 19.50 & 44.83 & 49.58 \\
\hline $\mathrm{V}_{2} \mathrm{G}_{3}$ & 18.67 & 43.17 & 48.30 \\
\hline $\mathrm{LSD}_{0.05}$ & 0.39 & 0.75 & 0.65 \\
\hline $\mathrm{LSD}_{0.01}$ & 0.53 & 1.02 & 0.89 \\
\hline $\begin{array}{l}\text { Level of } \\
\text { significance }\end{array}$ & $0.78 * *$ & $5.63 * *$ & $1.82 * *$ \\
\hline
\end{tabular}

$* *=$ Significant at $1 \%$ level of probability. $\mathrm{V}_{\mathrm{o}}, \mathrm{V}_{1}$, and $\mathrm{V}_{2}$ indicates no vernalization, vernalization at $5^{\circ} \mathrm{c}$ and $10^{\circ} \mathrm{c}$ for 14 days respectively and $\mathrm{G}_{0}, \mathrm{G}_{\mathrm{I}}, \mathrm{G}_{2}, \mathrm{G}_{3}$ indicates $0,50,100$ and 150 ppm respectively

\subsection{Combined Effect of Vernalization and $G A_{3}$ on Number of Leaves Plant-1}

The combined effect of vernalization and GA3 on the number of leaves per plant was found to be significant at 20,40 and 60 DAP. The variation among the treatment combinations was significant. At $60 \mathrm{DAP}$, the highest number of leaves (34.17) per plant was recorded from the treatment combinations of $\mathrm{V} 1 \mathrm{G} 2$ (vernalization at $5^{\circ} \mathrm{C}$ for 14 days with $100 \mathrm{ppm} \mathrm{GA3}$ ) while the lowest number of leaves (17.83) plant-1 was obtained from the V0G0 treatment combinations (Table 2).

Table 2. Combined effects of vernalization and $\mathrm{GA}_{3}$ concentration on number of leaves/plant of summer onion at different days after planting

\begin{tabular}{llll}
\hline \multirow{2}{*}{$\begin{array}{l}\text { Treatment } \\
\text { combination }\end{array}$} & \multicolumn{3}{c}{ No. of leaves/plant at } \\
\cline { 2 - 4 } & 20 & 40 & 60 \\
\hline $\mathrm{V}_{0} \mathrm{G}_{0}$ & 8.17 & 15.97 & 17.83 \\
$\mathrm{~V}_{0} \mathrm{G}_{1}$ & 10.33 & 18.50 & 21.17 \\
$\mathrm{~V}_{0} \mathrm{G}_{2}$ & 13.50 & 22.82 & 22.50 \\
$\mathrm{~V}_{0} \mathrm{G}_{3}$ & 11.17 & 18.83 & 21.67 \\
$\mathrm{~V}_{1} \mathrm{G}_{0}$ & 15.33 & 18.33 & 22.33 \\
$\mathrm{~V}_{1} \mathrm{G}_{1}$ & 16.00 & 19.60 & 32.00 \\
$\mathrm{~V}_{1} \mathrm{G}_{2}$ & 19.83 & 21.67 & 34.17 \\
$\mathrm{~V}_{1} \mathrm{G}_{3}$ & 17.89 & 20.08 & 33.00 \\
\hline
\end{tabular}




\begin{tabular}{|c|c|c|c|}
\hline $\mathrm{V}_{2} \mathrm{G}_{0}$ & 14.50 & 17.06 & 18.33 \\
\hline $\mathrm{V}_{2} \mathrm{G}_{1}$ & 15.67 & 18.93 & 22.83 \\
\hline $\mathrm{V}_{2} \mathrm{G}_{2}$ & 17.67 & 21.50 & 32.33 \\
\hline $\mathrm{V}_{2} \mathrm{G}_{3}$ & 16.67 & 19.77 & 30.17 \\
\hline $\mathrm{LSD}_{0.05}$ & 0.64 & 0.66 & 0.74 \\
\hline $\mathrm{LSD}_{0.01}$ & 0.87 & 0.90 & 1.00 \\
\hline $\begin{array}{ll}\text { Level } & \text { of } \\
\text { significance }\end{array}$ & $0.90 * *$ & $1.83 * *$ & $22.28^{* *}$ \\
\hline
\end{tabular}

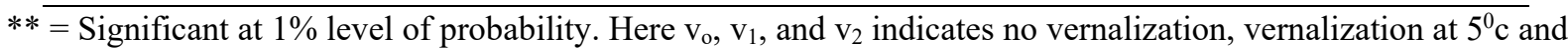
$10^{\circ} \mathrm{c}$ for 14 days respectively and $\mathrm{G}_{0}, \mathrm{G}_{\mathrm{I}}, \mathrm{G}_{2}, \mathrm{G}_{3}$ indicates $0,50,100$ and 150 ppm respectively

\subsection{Combined Effect of Vernalization and $\mathrm{GA}_{3}$ on Percent Germination of Summer Onion}

The combined effect of vernalization and $\mathrm{GA}_{3}$ on the percent germination per plant was found to be significant. The variation among the treatment combinations was significant. The highest percent germination (74.00) was recorded from the treatment combinations of $\mathrm{V}_{1} \mathrm{G}_{2}$ (vernalization at $5^{\circ} \mathrm{C}$ for 14 days with $100 \mathrm{ppm} \mathrm{GA}_{3}$ ) while the lowest percent germination (48.00) was obtained from the $\mathrm{V}_{0} \mathrm{G}_{0}$ treatment combinations (Table 3).

Table 3. Combined effects of vernalization and GA3 concentration on percent germination of summer onion

\begin{tabular}{cc}
\hline Treatment combination & Germination (\%) \\
\hline $\mathrm{V}_{0} \mathrm{G}_{0}$ & 48.00 \\
$\mathrm{~V}_{0} \mathrm{G}_{1}$ & 54.00 \\
$\mathrm{~V}_{0} \mathrm{G}_{2}$ & 60.00 \\
$\mathrm{~V}_{0} \mathrm{G}_{3}$ & 56.00 \\
$\mathrm{~V}_{1} \mathrm{G}_{0}$ & 54.00 \\
$\mathrm{~V}_{1} \mathrm{G}_{1}$ & 58.00 \\
$\mathrm{~V}_{1} \mathrm{G}_{2}$ & 74.00 \\
$\mathrm{~V}_{1} \mathrm{G}_{3}$ & 60.00 \\
$\mathrm{~V}_{2} \mathrm{G}_{0}$ & 50.00 \\
$\mathrm{~V}_{2} \mathrm{G}_{1}$ & 56.00 \\
$\mathrm{~V}_{2} \mathrm{G}_{2}$ & 62.00 \\
$\mathrm{~V}_{2} \mathrm{G}_{3}$ & 58.00 \\
$\mathrm{LSD}_{0.05}$ & 1.39 \\
$\mathrm{LSD}_{0.01}$ & 1.88 \\
Level of significance & $22.67 * *$ \\
\hline
\end{tabular}

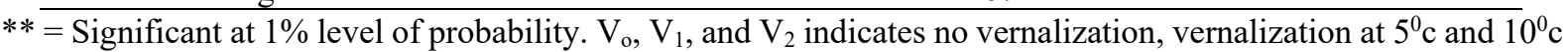
for 14 days respectively and $\mathrm{G}_{0}, \mathrm{G}_{\mathrm{I}}, \mathrm{G}_{2}, \mathrm{G}_{3}$ indicate $0,50,100$ and 150 ppm respectively

\subsection{Combined Effect of Vernalization and $G A_{3}$ on Flowers and Seed Characters at 60 DAP}

There was a significant variation in respect of height of flowering stalk, highest percent flowering, number of umbels plant ${ }^{-1}$, number of flowers plant ${ }^{-1}$, number of seeds umbel ${ }^{-1}$, number of fruits umbel ${ }^{-1}$ at 60 DAP due to different levels of vernalization and $\mathrm{GA}_{3}$. The longest flowering stalk $(86.92 \mathrm{~cm})$ was found in the plots which received $5^{\circ} \mathrm{C}$ vernalization for 14 days with $100 \mathrm{ppm} \mathrm{GA}_{3}$ while the shortest $(61.00 \mathrm{~cm})$ was recorded in the plant that received no vernalization and no $\mathrm{GA}_{3}$. The highest percent flowering (82.40) was found in the plots which received $5^{\circ} \mathrm{C}$ vernalization for 14 days with $100 \mathrm{ppm} \mathrm{GA}_{3}$ while the lowest $(71.65)$ was recorded in the plant that received no vernalization and no $\mathrm{GA}_{3}$. The maximum number of umbels plant ${ }^{-1}$, number of flowers umbel ${ }^{-1}(7.70$, 263.57) was found in the plant that received $5^{\circ} \mathrm{C}$ vernalization for 14 days with $100 \mathrm{ppm} \mathrm{GA}_{3}$ and minimum (4.19, 168.50) was observed respectively in the plant that received no vernalization and no $\mathrm{GA}_{3}$. The maximum number of seeds umbel ${ }^{-1}$, number of fruits umbel ${ }^{-1}(320.50,100.00)$ was found in the plant that received $5^{\circ} \mathrm{C}$ vernalization for 14 days with $100 \mathrm{ppm} \mathrm{GA}_{3}$ and minimum $(198.00,67.85)$ was observed respectively in the plant that received no vernalization and no $\mathrm{GA}_{3}$ (Table 4). 
Table 4. Combined effects of vernalization and $\mathrm{GA}_{3}$ concentration on quality seed production of summer onion

$\begin{array}{llllllll}\begin{array}{l}\text { Treatment } \\ \text { combination }\end{array} & \begin{array}{l}\text { Height } \\ \text { flowering stalk }\end{array} & \begin{array}{l}\text { Highest } \\ \text { percent } \\ \text { flowering }\end{array} & \begin{array}{l}\text { No. of } \\ \text { umbels/ } \\ \text { plant }\end{array} & \begin{array}{l}\text { No. } \\ \text { flowers/umbel }\end{array} & \begin{array}{l}\text { No. } \\ \text { seeds/ } \\ \text { umbel }\end{array} & \begin{array}{l}\text { of } \\ \text { fruits/ }\end{array} \\ \text { umbel }\end{array}$

** = Significant at $1 \%$ level of probability, $*$ = Significant at $5 \%$ level of probability. $\mathrm{V}_{\mathrm{o}}, \mathrm{V}_{1}$, and $\mathrm{V}_{2}$ indicates no vernalization, vernalization at $5^{\circ} \mathrm{c}$ and $10^{\circ} \mathrm{c}$ for 14 days respectively and $\mathrm{G}_{0}, \mathrm{G}_{\mathrm{I}}, \mathrm{G}_{2}, \mathrm{G}_{3}$ indicate $0 \mathrm{ppm}, 50 \mathrm{ppm}$, $100 \mathrm{ppm}$ and $150 \mathrm{ppm}$ respectively.

\subsection{Combined Effect of Vernalization and $G A_{3}$ at $60 \mathrm{DAP}$}

There was a significant variation in respect of number of fruits plant ${ }^{-1}$, percent fruits, weight of seeds umbel ${ }^{-1}$, 1000 seeds weight, weight of seeds plant ${ }^{-1}$, weight of seeds plot $^{-1}$ and seed yield due to different levels of vernalization and $\mathrm{GA}_{3}$. The highest number of fruits plant ${ }^{-1}$ (770.13) was found in the plots which received $5^{\circ} \mathrm{C}$ vernalization for 14 days with $100 \mathrm{ppm} \mathrm{GA} 3$ while the minimum (284.16) was recorded in the plant that received no vernalization and no $\mathrm{GA}_{3}$. The highest percent fruits set (41.97) was found in the plots which received $5^{\circ} \mathrm{C}$ vernalization for 14 days with $100 \mathrm{ppm} \mathrm{GA}$ while the lowest (38.40) was recorded in the plant that received no vernalization and no $\mathrm{GA}_{3}$. The maximum weight of seeds umbel ${ }^{-1}(1.22 \mathrm{~g})$ was found in the plant that received $5^{\circ} \mathrm{C}$ vernalization for 14 days with $150 \mathrm{ppm} \mathrm{GA}_{3}$ and minimum (0.31) was found in the plant having no vernalization and no $\mathrm{GA}_{3}$. The maximum 1000 seeds weight $(3.10 \mathrm{~g})$ was found in the plant that received $5^{\circ} \mathrm{C}$ vernalization for 14 days with $100 \mathrm{ppm} \mathrm{GA}$ and minimum $(2.10 \mathrm{~g})$ was observed in the plant that received no vernalization and no $\mathrm{GA}_{3}$. The maximum weight of seeds/plant $(7.29 \mathrm{~g})$ and weight of seeds/ plot $(66.68 \mathrm{~g})$ was found in the plant that received $5^{\circ} \mathrm{C}$ vernalization for 14 days with $100 \mathrm{ppm} \mathrm{GA}_{3}$ and minimum $1.84 \mathrm{~g} \mathrm{\&} 16.82 \mathrm{~g}$ was found in control respectively (Table 5).

Table 5. Combined effects of vernalization and $\mathrm{GA}_{3}$ concentration on quality seed production of summer onion

\begin{tabular}{ccccccc}
\hline $\begin{array}{c}\text { Treatment } \\
\text { combination }\end{array}$ & $\begin{array}{c}\text { No. of fruits/ } \\
\text { plant }\end{array}$ & $\begin{array}{c}\text { \% Fruit } \\
\text { set }\end{array}$ & $\begin{array}{c}\text { Weight of } \\
\text { seeds/ umbel } \\
(\mathrm{g})\end{array}$ & $\begin{array}{c}1000 \text { seed } \\
\mathrm{Wt}(\mathrm{g})\end{array}$ & $\begin{array}{c}\text { Weight of } \\
\text { seeds/ plant } \\
(\mathrm{g})\end{array}$ & $\begin{array}{c}\text { Weight of } \\
\text { seeds/ plot }(\mathrm{g})\end{array}$ \\
\hline $\mathrm{V}_{0} \mathrm{G}_{0}$ & 284.16 & 38.40 & 0.31 & 2.10 & 1.84 & 16.82 \\
$\mathrm{~V}_{0} \mathrm{G}_{1}$ & 354.13 & 38.75 & 0.42 & 2.24 & 2.51 & 22.92 \\
$\mathrm{~V}_{0} \mathrm{G}_{2}$ & 516.85 & 39.42 & 0.50 & 2.61 & 3.00 & 27.43 \\
$\mathrm{~V}_{0} \mathrm{G}_{3}$ & 443.34 & 39.20 & 0.46 & 2.37 & 2.76 & 25.23 \\
$\mathrm{~V}_{1} \mathrm{G}_{0}$ & 389.72 & 39.37 & 0.95 & 2.30 & 5.67 & 51.84 \\
\hline
\end{tabular}




\begin{tabular}{ccccccc}
\hline $\mathrm{V}_{1} \mathrm{G}_{1}$ & 583.33 & 40.33 & 1.01 & 2.52 & 6.08 & 55.62 \\
$\mathrm{~V}_{1} \mathrm{G}_{2}$ & 770.13 & 41.97 & 1.13 & 3.10 & 7.29 & 66.68 \\
$\mathrm{~V}_{1} \mathrm{G}_{3}$ & 656.95 & 41.67 & 1.22 & 2.75 & 6.77 & 61.90 \\
$\mathrm{~V}_{2} \mathrm{G}_{0}$ & 333.99 & 38.67 & 0.59 & 2.15 & 3.51 & 32.09 \\
$\mathrm{~V}_{2} \mathrm{G}_{1}$ & 419.35 & 39.19 & 0.63 & 2.31 & 3.75 & 34.29 \\
$\mathrm{~V}_{2} \mathrm{G}_{2}$ & 621.53 & 40.22 & 0.78 & 2.75 & 4.67 & 42.70 \\
$\mathrm{~V}_{2} \mathrm{G}_{3}$ & 540.03 & 39.61 & 0.70 & 2.49 & 4.22 & 38.58 \\
$\mathrm{LSD}_{0.05}$ & 20.62 & 0.47 & 0.05 & 0.08 & 0.15 & 2.96 \\
$\mathrm{LSD}_{0.01}$ & 28.02 & 0.64 & 0.07 & 0.10 & 0.21 & 4.02 \\
Level of & $3616.03^{* *}$ & $0.50^{* *}$ & $0.01 * *$ & $0.01 * *$ & $0.21^{* *}$ & $83.57^{* *}$ \\
significance & & & & & \\
\hline
\end{tabular}

$* *=$ Significant at $1 \% 1$ evel of probability, $*=$ Significant at $5 \%$ level of probability. $\mathrm{V}_{\mathrm{o}}, \mathrm{V}_{1}$, and $\mathrm{V}_{2}$ indicates no vernalization,vernalization at $5^{\circ} \mathrm{c}$ and $10^{\circ} \mathrm{c}$ for 14 days respectively and $\mathrm{G}_{0}, \mathrm{G}_{\mathrm{I}}, \mathrm{G}_{2}, \mathrm{G}_{3}$ indicate $0 \mathrm{ppm}, 50$ ppm, $100 \mathrm{ppm}$ and $150 \mathrm{ppm}$ respectively.

\subsection{Combined Effect of Vernalization and GA3 on Seed Yield}

The combined effect of vernalization and GA3 on seed yield. The highest seed yield $\left(280.42 \mathrm{~kg} \mathrm{ha}^{-1}\right)$ was found in the plots which received $5^{\circ} \mathrm{C}$ vernalization for 14 days with $100 \mathrm{ppm} \mathrm{GA3}$ while the lowest seed yield (70.75 $\mathrm{kg} \mathrm{ha}^{-1}$ ) was recorded in the plant that received no vernalization with no GA3 (Fig. 1).

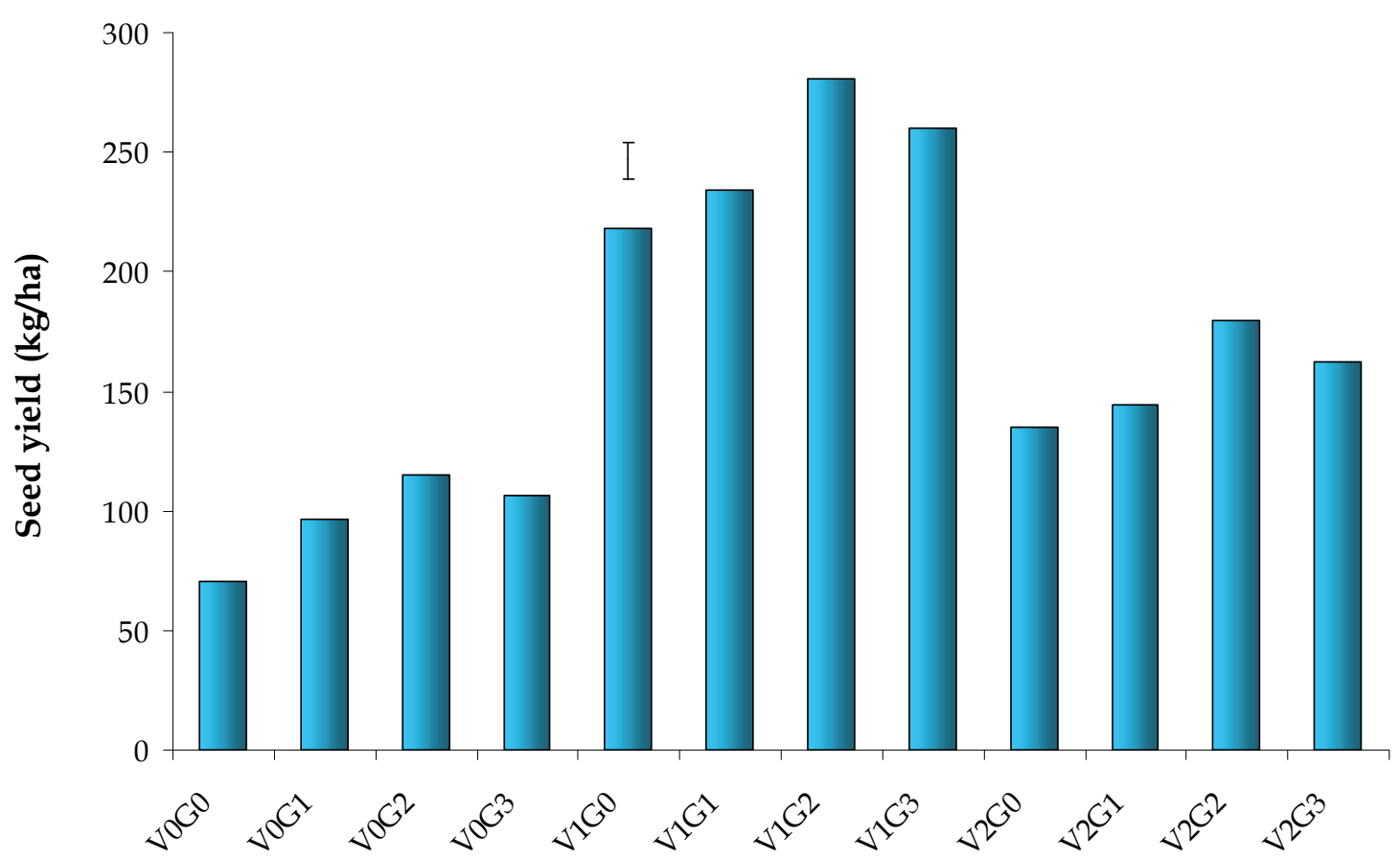

Treatment combination

Figure 1. Combined effects of vernalization and $\mathrm{GA}_{3}$ concentration on quality seed production of summer onion. $\mathrm{V}_{\mathrm{o}}, \mathrm{V}_{1}, \& \mathrm{~V}_{2}$ indicates no vernalization, vernalization at $5^{\circ} \mathrm{C}$ and $10^{\circ} \mathrm{C}$ for 14 days respectively and $\mathrm{G}_{0}, \mathrm{G}_{\mathrm{I}}, \mathrm{G}_{2}$, $\mathrm{G}_{3}$ indicate $0 \mathrm{ppm}, 50 \mathrm{ppm}, 100 \mathrm{ppm}$ and $150 \mathrm{ppm}$ respectively

\section{Discussion}

Data were collected from six randomly selected plants and seed yield was recorded from all plants of unit plots. Observations were made on plant height, number of leaves plant-1, percent germination, height of flowering stalk, highest percent flowering, number of umbels plant- 1 , number of flowers plant-1, number of seeds umbel-1, number 
of fruits umbel-1 at 60 DAP number of fruits plant-1, percent fruits, weight of seeds umbel-1, 1000 seeds weight, weight of seeds plant-1, weight of seeds plot-1 and seed yield. The collected data were statistically analyzed and the means were compared with LSD values.

The treatment combination of vernalization at $5^{\circ} \mathrm{Cfor} 14$ days with the $100 \mathrm{ppm}$ GA3 gave the highest values of plant height at 60 DAP $(52.75 \mathrm{~cm})$, the maximum number of leaves (34.17), the maximum germination at (74.00 percent), height of flowering stalk (86.92), highest percent flowering (82.40), number of umbels plant-1 (7.70), number of flowers plant-1 (263.57), number of seeds umbel-1 (320.50), number of fruits umbel-1 (100.00), number of fruits plant-1 (770.13), percent fruits (41.97), weight of seeds umbel-1 (1.13), 1000 seeds weight (3.10), weight of seeds plant-1 (7.29), weight of seeds plot-1 (66.68) and seed yield (280.42) were observed with the vernalization at $5^{\circ} \mathrm{C}$ for 14 days and $100 \mathrm{ppm}$ GA3. Whereas the lowest values of all other parameters were found in the vernalization control with $100 \mathrm{ppm} \mathrm{GA3}$ treatment. A combination of Vernalization at $5^{\circ} \mathrm{C}$ for 14 days and 100 ppm GA3 considerably helped to produce early flowering and good quality heavier onion seed yield. Usually, a flowering stalk may consist of 50 to 2000 flowers (Jones and Mann, 1963).

Muthamia (1994), Khokhar (2009) proves that cold treatment enhances scape emergence. The emergence and differentiation of scape depend on temperature (Zemah et a., 2001). Vernalization treatment mostly alters the source-sink relation in favor of reproductive growth (Linwattana et al., 1997). According to (Streck, 2003), the temperature reaction of vernalization in onion (Allium cepa L.) was described as having cardinal temperatures of $0{ }^{\circ} \mathrm{C}, 10{ }^{\circ} \mathrm{C}, 16^{\circ} \mathrm{C}$. The observed vernalization response to the temperature of various onion cultivars and the temperature response curve predicted with the beta function. The observed data proved a maximum response in the range of $9-12{ }^{\circ} \mathrm{C}$ and a reduction when temperature departs from optimum temperature. A higher proportion of scape emergence and greater uniformity in floral initiation was observed when at $10^{\circ} \mathrm{C}$ increased as the length of vernalization (D'Angelo and Goldman 2019). In the case of onion, a comparison of the cardinal temperatures for vernalization $\left(0{ }^{\circ} \mathrm{C}, 10{ }^{\circ} \mathrm{C}, 16^{\circ} \mathrm{C}\right)$ with other species gives some similarities and differences. The cardinal temperatures for vernalization in carrot are $-1,6.5$, and $16^{\circ} \mathrm{C}$ (Atherthon et al., 1990), in lily, are 0,5 , and $21^{\circ} \mathrm{C}$ (Roh \& Wilkins, 1977; Roh, 1985; Holcomb \& Berghage, 2001); in calabrese is -2.8, 15.8, and $23.6^{\circ} \mathrm{C}$ (Wurr et al., 1995); and in winter wheat are $-1.3,4.9$, and $15.7^{\circ} \mathrm{C}$ (Porter \& Gawith, 1999). Vernalization treatment of 10 $0 \mathrm{C}$ for 10 days is effective in enhancing the seed yield in onion (Yalamalle 2016). Low temperatures exposure (in natural or artificial conditions) that causes induction of flowering is called vernalization (Lee et al., 2013; Thomas and Vince-Prue, 1997) Due to incomplete vernalization seed yield will be poor (Voss et al., 2013). The increase in yield could be characterized by the more number of flowers in vernalized plants. The results are similar to the previous findings of Msika et al. (1997); Khokhar (2009). According to (Brewster, 1994) at the time of thermo phase the onion seed crop apart from temperature, high concentration of soluble carbohydrates is an important factor enhancing flowering in onion and bulbing of Alliums. Benkeblia et al. (2004) noticed that the higher activity of soluble invertase, glucose, sucrose, and fructose levels in onion bulbs stored at $10{ }^{\circ} \mathrm{C}$ than those stored at $20^{\circ} \mathrm{C}$. Vernalization helped in the conversion of complex sugars in the bulbs to simple sugars which were deliberately available for transition to reproductive growth. These increased in number of flowers and the increase of seed yield subsequently (Yalamalle 2016). Flowering in bolting resistant cultivars can be particularly difficult and large bulb size or long treatment at low temperature may be required (Shishido and Saito 1977). The optimum duration to completely vernalize onion cultivars at low temperatures $\left(3\right.$ to $\left.11^{\circ} \mathrm{C}\right)$ is in the range of 7 to 90 days (Woodbury 1950; Kruzhilin and Shvedskaya 1962; Rabinowitch 1985; Pike 1986; Bertaud, 1988; Peters, 1990; Rabinowitch, 1990). The seed stalk elongation rate was increased by higher temperatures and long photoperiods (Brewester, 1982 and Brewester 1987). The variation in the results of seed stalk length during both seasons could be characterized by the effect of the environment, because the genotypes used were identical (Elsiddig et al., 2015). Geetharani et al., 2008 noticed that 100 ppm GA3 spray increased the flowering by $47 \%$. Naamni et al. (1980) \& Looper and Waller (1982) investigated that 30-40\% increase in seed yield due to GA3 application. A better part of the plants with GA3 treatment exhibited stunted growth and were chlorotic in appearance shows the toxic effect mostly due to high dosage (Yalamalle 2016). Vernalization of bulbs (cultivar -Texas Early Grano) at $4-5^{\circ} \mathrm{C}$ for 180 days with the application of GA3 at the rate of $600 \mathrm{ppm}$ for seed production is suitable under Gezira state (Sudan) conditions (Elsiddig et al., 2015). GA3 increased the number of flowers per plant, length of flower stalks, and seed yield per plant. The highest seed yield was achieved with the application of GA3 at 75 ppm (Bhople et al., 1999). Without vernalization, application of GA3 singly, all the concentrations tested failed to induce flowering of onion (cultivar - Texas Early Grano) when planted offseason but it accelerated the effect of vernalization on bolting and seed production (Elsiddig et al., 2015). 


\section{Conclusion}

To obtain the highest seed yield and quality seeds of summer onion the combination of vernalization at $5^{\circ} \mathrm{C}$ for 14 days and 100 ppm GA 3 may be suggested to Mymensingh region. This experiment may be repeated under different agro-climatic regions of Bangladesh.

\section{Acknowledgement}

The author takes an opportunity to express thier gratefulness to Ministry of Science and Technology, The People's Republic of Bangladesh for awarding the National Science and Technology (NST) Fellowship which had the financial contribution on the successful completion of this research and thesis work

\section{Conflict of interest}

The authors have no conflict of interest to report

\section{References}

Atherton, J. G., Craigon, J., \& Basher, E. A. (1990). Flowering and bolting in carrot. I. Juvenility, cardinal temperatures and thermal times for vernalization. Journal of Horticultural Science, Ashford, 65(4), 423-429. https://doi.org/10.1080/00221589.1990.11516075

Benkeblia, N., Onodera, S., Yoshihira, T., Kosaka, S., \& Shiomi, N. (2004). Effect of temperature on soluble invertase activity, and glucose, fructose and sucrose status of onion bulbs (Allium cepa L.) in store. International Journal of Food Science and Nutrition, 55(4), 325-331. https://doi.org/10.1080/09637480412331290512

Bertaud, D. S. (1988). Effects of chilling duration photoperiod and temperature on floral initiation and development in sprouted and unsprouted onion bulbs.In: Proceedings of the fourth EUCARPIA Allium Symposium, Institute of Horticultural Research, Wellesbourne, UK, pp. 245-261.

Bhople, S. R., Dod, V. N., Bharad, S. G., Gholap, S. V., \& Jadhao, B. (1999). Seed Production of Onion as Influenced by the Application of Growth Regulators. Journal of Soils and Crops, 9(1), 78-79.

Brewester, J. L. (1982). Flowering and seed production in over wintered cultivars of bulb onion, I. Effects of different raising environments, temperatures and day lengths. Journal of Horticultural Sciences, 57, $93-96$. https://doi.org/10.1080/00221589.1982.11515028

Brewster, J. L. (1983). Effects of photoperiod, nitrogen nutrition and temperature on inflorescence initiation and development in ionion (Allium cepa L.). Annals of Botany, London, 51(4), 429-440. https://doi.org/10.1093/oxfordjournals.aob.a086487

Brewster, J. L. (1987). Vernalization in the onion - a quantitative approach. In: ATHERTON, J.G. Manipulation of flowering. London: Butterworths, Cap. 13, 171-183. https://doi.org/10.1016/b978-0-407-00570-9.500181

Brewster, J. L. (1994). Onion and Other Vegetable Alliums. CAB International, UK.236p.

Corgan, J. N., \& Montano, T. M. (1975). Bolting and other responses of onion (Allium cepa L.) to growth regulating chemicals. J Amer Soc Hort Sci., 100(3), 273-227.

D’Angelo, C., J. \& Goldman, I. L. (2019). Annualization of the Long Day Onion Breeding Cycle through Threshold Vernalization and Dormancy Disruption. Crop Breed Genet Genom, 190009. https://doi.org/10.20900/cbgg20190009

Elsiddig, E. A. M., Elamin, O. M., \& Elkashif, M. E. (2015). Induction of Flowering in Texas Early Grano Onion Cultivar Using Vernalization and Gibberellic Acid under Gezira State Conditions, Sudan. International Journal of Scientific and Research Publications, 5(9).

Flood, R. G., \& Halloran, G. M. (1986). Genetics and physiology of vernalization response in wheat. Advances in Agronomy, New York, 39(1), 87-125. https://doi.org/10.1016/s0065-2113(08)60466-6

Geetharani, P., Manivannan, M. I., \& Ponnuswamy, A. S. (2008). Seed production of onion as influenced by the application of growth regulators and nutrients. Asian Journal of Horticulture, 3(2), 301-303.

Gomez, K. A., \& Gomez, A. A. (1984). Statistical Procedures for Agricultural Research. New York: John Wiley and Sons Inc. New York 67-215.

Hodges, T., \& Ritchie, J. T. (1991). The Ceres-Wheat phenology model. In: HODGES, T. Predicting crop phenology. Boston: CRC Press. Cap., 12, 133-141. 
Holcomb, E. J., \& Berghage, R. (2001). Photoperiod, chilling, and light quality during daylight extension affect growth and flowering of tissue-cultured Easter lily plants. HortScience, Mt. Vernon, 36(1), 53-55. https://doi.org/10.21273/hortsci.36.1.53

Jones, A., Saxena, P. K., \& Murch, S. J. (2009). Elicitation of Secondary Metabolism in Echinacea purpurea L. by Gibberellic Acid and Triazoles. Eng Life. https://doi.org/10.1002/elsc.200800104

Jones, H. A., \& Mann, L. K. (1963). Onions and their Allies. Leonard Hill, (Books) Ltd., London. pp. 1-169.

Khokhar, K. M. (2009). Effect of set-size and storage temperature on bolting, bulbing and seed yield in two onion cultivars. Scientia Horticulturae, 122, 187-194. https://doi.org/10.1016/j.scienta.2009.05.008

Khokhar, K. M. (2014). Flowering and Seed Development in Onion-A Review. Open Access Library Journal, 1, e1049. http://dx.doi.org/10.4236/oalib.1101049

Kimani, P. M., Peters, R., \& Rabinowitch, H. D. (1994). Potential of onion seed production in a tropical environment. Acta Horticulturae, Wageningen, 351-348. https://doi.org/10.17660/actahortic.1994.358.56

Kruzhilin, A. S., \& Shvedskaya, Z. M. (1962). Peculiarities of phasic development and morphogenesis in onion (Allium cepa L.). Fiziologia Rastenii, 9, 466-475 [Translated] (cited by Rabinowitch, 1990).

Lee, R., Baldwin, S., Kenel, F., McCallum, J., \& Macknight, R. (2013). Flowering Locus T genes control onion bulb formation and flowering. Nature Communications, 4, 2884. https://doi.org/10.1038/ncomms3884

Linwattana, G., Protacio, C. M., \& Mabesa, R. C. (1997). Tropical low land seed production of non- heading Chinese cabbage (Brassica rapa L. pekinensis group) using vernalization and gibberellic acid Philippine. Journal of Crop Science, 22(3), 161-166

Loper, G. M., \& Waller, G. D. (1982). GA3-increased bolting and seed production in late-planted onions. Hortscience, 17(6), 922-923.

Msika, R. L., Jackson, J. E., \& Currah, L. (1997). Onion Seed Production Trials in the Highveld of Zimbabwe. Acta Horticulturae, 433, 337-346. https://doi.org/10.17660/actahortic.1997.433.36

Muthamia, K. W. (1994). Effect of bulb size and duration of vernalization on onion (Allium cepa L.) seed yield. MSc thesis University of Nairobi. Retrieved from http:// erepository.uonbi.ac.ke/handle/11295/23061.

Naamni, F., Rabinowitch, H. D., \& Kedar, N. (1980). The effect of GA3 application on flowering and seed production in onion. Journal of the American Society for Horticultural Science, 105(2), 164-167.

Olszewski, N., Sun, T. P., \& Gubler, F. (2002) Gibberellin signaling: biosynthesis, catabolism, and response pathways. Plant Cell, (14), S61-S80. https://doi.org/10.1105/tpc.010476

Peters, R. (1990). Seed production in onions and some other Allium species. In Rabinowitch, H. D., Brewster, J. L. (Eds.), Onions and Allied Crops (Vol. I. pp.161-176). Botany, Physiology and Genetics. CRC Press, Boca Raton, Florida. https://doi.org/10.1201/9781351075169-8

Pike, L. M. (1986). Onion breeding. In Basset, M. J. (Ed.), Breeding Vegetable Crops. AVI Publishing Co., Connecticut (pp. 357-394).

Pinthus, M. J. (1985). Triticum. In HALEY, H.C. CRC, Handbook of flowering (Volume IV, pp. 418-443). Boca Raton: CRC Press. https://doi.org/10.1201/9781351072564-59

Porter, J. R., \& Gawith, M. (1999). Temperatures and the growth and development of wheat: a review. European Journal of Agronomy, Montrouge Cedex, 10(1), 23-36.

Rabinowitch, H. D. (1990). Physiology of flowering. In Rabinowitch, H. D., \& Brewster, J. L. (Eds.), Onions and Allied Crops (Vol. I., pp. 133-134), Botany, Physiology and Genetics. CRC Press, Boca Raton, Florida. https://doi.org/10.1201/9781351075169-5

Rabinowitch, H. D. (1985). Onions and other edible Alliums. In Halevy, A. H. (Ed.), CRC Handbook of Flowering (Vol. I., pp. 398-405). CRC Press, Boca Raton, Florida.

Ritchie, J. T. (1991). Modeling Plant and Soil Systems. Madison: ASA, CSSA, and SSSA, Cap. 3, 31-54.

Rizk, F. A., Shaheen, A. M., \& El-Habbasha, K. M. (1996). Flowering and seed yield of onion (Allium cepa L.) plants as affected by dates of planting and some growth regulators. Egypt J Hort., (23), 113-127.

Roh, M. S. (1985). Flowering response of mid-century hybrid lilies to bulb vernalization and shoot photoperiod treatment. HortScience, Mt. Vernon, 20(4), 710-713. 
Roh, M. S., \& Wilkins, H. F. (1977). Comparison of continuous and alternating bulb temperature treatments on the growth and flowering in Lilium longiflorum Thunb. Journal of the American Society for Horticultural Science, Boston, 102(3), 242-247.

Sekara, A., Pokluda, R., Del Vacchio, L., Somma, S., \& Caruso, G. (2017): Interactions among genotype, environment and agronomic practices on production and quality of storage onion (Allium cepa L.) - A review. Hort. Sci. (Prague), 44, 21-42. https://doi.org/10.17221/92/2015-hortsci

Shaikh, A. M., Vyakaranahal, B. S., Shekhargouda, M., \& Dharmatti, P. R. (2002). Influence of Bulb Size and Growth Regulators on Growth, Seed Yield and Quality of Onion cv. Nasik Red. Seed Research, 30(2), 223229.

Sharma, N., Kaur. N., \& Gupta, A. K. (1999). Effects of gibberellic acid and chlorocholine chloride on tuberisation and growth of potato (Solanum tuberosum L.). $J$ Sci Food Agric., 78(4), 466-470. https://doi.org/10.1002/(sici)1097-0010(199812)78:4<466::aid-jsfa140>3.0.co;2-1

Shaykewich, C. F. (1995). An appraisal of cereal crop phenology modeling. Canadian Journal of Plant Science, Ottawa, 75(2), 329-341. https://doi.org/10.4141/cjps95-057

Shishido, Y., \& Saito, T. (1977). Studies on the flower bud formation in onion plants. III. Effects of physiological conditions on the low temperature induction of flower buds in bulbs. J. Jpn. Soc. Horticult. Sci., 46, 310-316. (Japanese, En. Sum).

Streck, N. A. (2003). A VERNALIZATION MODEL IN ONION (Allium cepa L.). MODELO DE VERNALIZAÇÃO EM CEBOLA (Allium cepa L.). Departamento de Fitotecnia, Centro de Ciências Rurais, Universidade Federal de Santa Maria. 97105-900 - Santa Maria, RS, Brasil. https://doi.org/10.21475/ajcs.18.12.12.p1434

Streck, N. A. (2002a). A generalized nonlinear air temperature response function for node appearance rate in muskmelon (Cucumis melo L.). Revista Brasileira de Agrometeorologia, Santa Maria, 10(1), 105-111.

Thomas, B., \& Vince-Prue, D. (1997). Photoperiodism in Plants. Academic Press, San Diego.

Ubeda Tomas, S., Federici, F., \& Casimiro I, (2009). Gibberellin signaling in the endodermis controls arabidopsis root meristem size. Curr Biol., 19(14), 1194-1199. https://doi.org/10.1016/j.cub.2009.06.023

Voss, R. E., Murray, M., Bradford, K., Mayberry, K., Miller, I., Long, R., \& Gillespie, S. (2013). Onion seed production in California. https://doi.org/10.3733/ucanr.8008

Woodbury, G. W. (1950). A study of factors influencing floral initiation and seed stalk development in the onion, Allium cepa L. Idaho Agricultural Experiment Station Research Bulletin No. 18.

Wurr, D. C. E., Fellows, J. R., \& Phelps, K. (1995). Vernalization in calabrese (Brassica oleracea var. italica) - a model for apex development. Journal of Experimental Botany, Oxford, 46(291), 1487-1496. https://doi.org/10.1093/jxb/46.10.1487

Yalamalle, V. R. (2016). Vernalization Responses in Onion (Allium cepa) Pre-flowering and Reproductive Phases. ICAR-Directorate of Onion and Garlic Research, Rajgurunagar, Pune (412 105), India. International Journal of Bio-resource and Stress Management, 7(6), 1413-1417. https://doi.org/10.23910/ijbsm/2016.7.6.1728a

Zemah, H., Rabinowitch, H. D., \& Kamenetsky, R. (2001). Florogenesis and the effect of temperatures on the development of Allium aflatunense. Journal of Horticultural Science \& Biotechnology, 76, 507-513. https://doi.org/10.1080/14620316.2001.11511401

\section{Copyrights}

Copyright for this article is retained by the author(s), with first publication rights granted to the journal.

This is an open-access article distributed under the terms and conditions of the Creative Commons Attribution license (http://creativecommons.org/licenses/by/4.0/). 